\title{
News from ACRL Headquarters
}

Actions taken by the ACRL Board at its most recent board meeting were reported in the last issue of $C$ \& $R L$ News. Among the actions reported was one which stated that "the Executive Secretary be given a column in $C \& R L$ News for direct communication to the membership and to report activities to the regional chapters." This column is the first of what we plan to be a continuing feature each month in the News.

Two activities in which ACRL has been involved this past month have dealt with the implementation of AACR 2 and the closing of the card catalog, and planning for a new library management program that will affect college and two-year college libraries.

The ALA executive director called a meeting of organizations concerned with the implementation of the second edition of Anglo-American Cataloguing Rules. In addition to the national library associations, representatives from OCLC, BALLOTS, the Washington Library Network, the National Library of Medicine, and the Library of Congress attended. The result of the meeting was a unanimously approved resolution to the Library of Congress to delay the implementation of AACR 2 and the closing of its catalog until Janu- ary 1, 1981. This will provide more time for libraries to determine what the impact of AACR 2 will be on their operations.

ACRL President Evan Farber and Executive Secretary Julie Virgo spent two days with the Office of University Library Management Studies/Association of Research Libraries staff to begin the planning process for implementing a $\$ 826,500$ project to help a large number of academic libraries improve their effectiveness through self-study programs. Named the Academic Library Program (ALP), the activity is being funded by grants from the Council on Library Resources, The Andrew W. Mellon Foundation, and the Association of Research Libraries.

The program will build on work previously carried out by OMS for primarily large research libraries, and will extend that work so that tools and methods will be appropriate for smaller academic libraries. Over a five-year period about one hundred outstanding librarians will be trained to serve as consultants; they will be provided with specialized guides and manuals and will be given backup assistance when appropriate.

More details on the program will be given in future columns from the ACRL headquarters.

\section{Getting Involved in ALA and ACRL}

Beginning professional librarians sometimes ask how to get involved in national library affairs. Being involved carries with it a number of rewards: acquaintance with national leaders, an inside knowledge of professional matters, and the feeling that an individual can help to shape national policies.

The answer is almost absurdly simple. Go where the action is, and be ready to offer help when an opportunity occurs. Begin by attending the Annual Conference of the American Library Association. Read the program carefully. It will list not only the major programs but also nearly a thousand committee meetings, all open to the public. It is at these meetings you will find your best contacts. Choose two or three committees concerned with topics that appeal to you and attend their meetings. Most committees are very small, sometimes only five or six members sitting around a table surrounded by a larger circle of chairs for observers.

Listen to the proceedings, sign the visitors' attendance sheet, and let the committee get used to seeing you there. Sooner or later a committee member will propose a project that requires more people for its achievement; it is perfectly natural for the committee to draft subcommittee members from those already on the scene. Volunteer for simple tasks which anyone can do: addressing envelopes, taking notes. Then follow through. Before you know it, you will have established a reputation as a dependable worker. When vacancies occur, your name will be remembered.

Your next conference will be much more rewarding; you will be part of the action. Catharine J. Reynolds, Head, Government Publications, University of Colorado Libraries at Boulder.

\section{Worksheet on How to Use Resources in Education}

This "Worksheet on How to Use Resources in Education" has been prepared by the ACRL EBSS Committee on Bibliographic Instruction for Educators. It has been approved by the full committee and by all of the members of the EBSS Executive Board.

The committee feels that the worksheet will be very useful for librarians who offer instruction in the use of ERIC.

For further information contact Patricia S. Butcher, Chairperson, EBSS Committee on Bibliographic Instruction for Educators, Readers' Adviser in Education. Trenton State College Library. Trenton, NJ 08625. 